\title{
Coal Technology Program Progress Report for October 1977
}

\section{OAK RIDGE NATIONAL LABORATORY} OPERATED BY UNION CARBIDE CORPORATION · FOR THE DEPARTMENT OF ENERGY 


\section{DISCLAIMER}

This report was prepared as an account of work sponsored by an agency of the United States Government. Neither the United States Government nor any agency Thereof, nor any of their employees, makes any warranty, express or implied, or assumes any legal liability or responsibility for the accuracy, completeness, or usefulness of any information, apparatus, product, or process disclosed, or represents that its use would not infringe privately owned rights. Reference herein to any specific commercial product, process, or service by trade name, trademark, manufacturer, or otherwise does not necessarily constitute or imply its endorsement, recommendation, or favoring by the United States Government or any agency thereof. The views and opinions of authors expressed herein do not necessarily state or reflect those of the United States Government or any agency thereof. 


\section{DISCLAIMER}

Portions of this document may be illegible in electronic image products. Images are produced from the best available original document. 


\begin{tabular}{c}
\hline Printed in the United States of America. Available from \\
National Technical Information Service \\
U.S. Department of Commerce \\
5285 Port Royal Road, Springfield, Virginia 22161 \\
Price: Printed Copy $\$ 5.25$, Microfiche $\$ 3.00$ \\
$\$ .50$
\end{tabular}

This report was prepared as an account of work sponsored by an agency of the United States Government. Neither the United States Government nor any agency thereof, nor any of their employees, contractors, subcontractors, or their employees, makes any warranty, express or implied, nor assumes any legal liability or responsibility for any third party's use or the results of such use of any information, apparatus, product or process disclosed in this report, nor represents that its use by such third party would not-infringe privately owned rights. 
Contract No. W-7405-eng-26

COAL TECHNOLOGY PROGRAM

PROGRESS REPORT FOR OCTOBER 1977

Date Published - December 1977

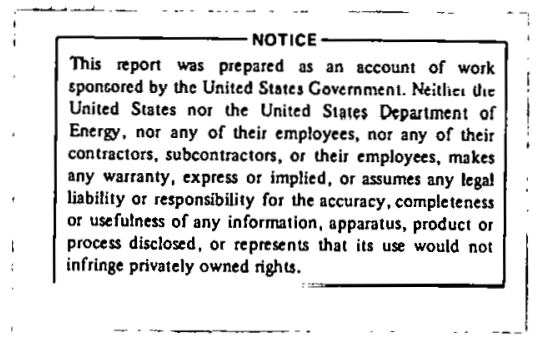

NOTICE This document contains information of a preliminary nature. it is subject to revision or correction and therefore does not represent a final report.

OAK RIDGE NATIONAL LABORATORY

Oak Ridge, Tennessee 37830

operated by

UNION CARBTDE CORPORATION

for the

DEPARTMENT OF ENERGY 


\section{PREVIOUS REPORTS IN THIS SERIES}

ORNL/TM-5044, Progress Report for August 1974

ORNL/TM-5045, Progress Report for September 1974

ORNL/TM-5046, Progress Report for October 1974

ORNL/TM-4787, Progress Report for November 1974

ORNL/TM-4796, Progress Report for December 1974

ORNL/TM-4850, Progress Report for January 1975

ORNL/TM-4873, Progress Report for February 1975

ORNL/TM-4892, Progress Report for March 1975

ORNL/TM-4946, Progress Report for April 1975

ORNL/TM-4966, Progress Report for May 1975

ORNL/TM-5010, Progress Report for June 1975

ORNL/TM-5037, Progress Report for July 1975

ORNL/TM-5092, Progress Report for August 1975

ORNL/TM-5124, Progress Report for September 1975

ORNL/TM-5186, Progress Report for October 1975

ORNL/TM-5214, Progress Report for November 1975

ORNL/TM-5246, Progress Report for December 1975

ORNL/TM-5301, Progress Report for January 1976.

ORNL/TM-5321, Progress Report for February 1976

ORNL/TM-5430, Progress Report for March 1976

ORNL/TM-5479, Progress Report for April 1976

ORNL/TM-5532, Progress Report for May 1976

ORNL/TM-5595, Progress Report for June 1976

ORNL/TM-5611, Progress Report for July 1976

ORNL/TM-5654, Progress Report for August 1976

ORNL/TM-5674, Progress Report for September 1976

ORNL/TM-5717, Progress Report for October 1976

ORNL/TM-5752, Progress Report for November 1976

ORNL/TM-5770, Progress Report for December 1976

ORNL/TM-5819, Progress Report for January 1977

ORNL/TM-5858, Progress Report for February 1977

ORNL/TM-5883, Progress Report for March 1977

ORNL/TM-5932, Progress Report for April 1977

ORNL/TM-5980, Progress Report for May 1977

ORNL/TM-6003, Progress Report for June 1977

ORNL/TM-6038, Progress Report for July 1977

ORNL/TM-6066, Progress Report for August 1977

ORNL/'I'M-6104, Progress Report for September 1977 
CONTENTS

Abstract . . . . . . . . . . . . . . . . . . . . . 1

1. Summary . . . . . . . . . . . . . . . . . . . . 1

2. Coai Conversion Process Development ............. . 4

2.1 Hydrocarbonization Research . . . . . . . . . . . 4

2.2 Experimental Engineering support of an In Situ Gasification Process . . . . . . . . . . . 5

2.3 Pressurized Carbonization of Coal Liquefaction Residue . . . . . . . . . . . . . 14

2.4 References for Section 2 . . . . . . . . . . . . . 14

3. Materials Engineering . . . . . . . . . . . . . . 16

3.1 Pressure Vessel and Piping Materials . . . . . . . . . 17

3.2 Inspection Techniques for Wear- ard ProcessResistant Coatings . . . . . . . . . . . . . . 17

3.3 Fossil Energy Welding and Cladding Program . . . . . . . 19

3.4 Fireside Corrosion of Atmospheric-Fluidized-Bed Combustor Tubes . . . . . . . . . . . . . . 19

3.5 Failure Analysis and Prevention. . . . . . . . . . 20

4. Alkali Metal Vapor Topping Cycles . . . . . . . . . . . 22

4.1 Gas-Fired Potassium Boiler ... . . . . . . . . . 22

5. Coa1 Equipment Test Facility .. . . . . . . . . . . . 23

5.1 Support for TRW Study . . . . . . . . . . . . . . 23

5.2 Coal Feeder Test Program . . . . . . . . . . . . 23

6. AFB Coal Combustor for Cogeneration (CCC) . . . . . . . . . . 24

6.1 Supplemental Studies . . . . . . . . . . . . 24

7. Engineering Studies and Technical Support . . . . . . . . . . 26

7.1 Process Modeling . . . . . . . . . . . . . . 26

7.2 Synthetic Fuels Process Research Digest . . . . . . . . . 27

7.3 Survey of Industriai Coal Conversion Equipment Capabilities . . . . . . . . . . . . . 27

7.4 Support of Initial Operations . . . . . . . . . . . 28

7.5 Flash Hydropyrolysis . . . . . . . . . . . . . 29

7.6 Hot Gas Purification Processes . . . . . . . . . . . 29 
7.7 State-of-the-Art Review of Heat Recovery Processes . . . . . 30

7.8 Assessment of a moving Bed System for Cleanup of Raw Gasifier Gas . . . . . . . . . . . . . 31

7.9 Technical/Economic Assessment of Hydrogen Production by the Steam/Molten Iron Process . . . . . . . 32

7.10 A Study of Effluent Control Technologies for Hydrocarbon and Carbon Monoxide Emissions from Coal Conversion Plants . 32

8. Process and Program Analysis . . . . . . . . . . . . 34

8.1 Low Btu Coal Gasification . . . . . . . . . . . . 34

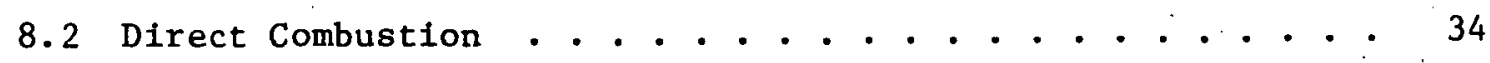

8.3 Advanced Power Conversion Systems . . . . . . . . . . 35

8.4 Liquefaction . . . . . . . . . . . . . . . . . 35

8.5 High Btu Gas... . . . . . . . . . . . . . . 36

8.6 In Situ Coal Gasification . . . . . . . . . . . . 36

8.7 Coal Beneficiation. . . . . . . . . . . . . . . 37

8.8 Gas Cleanup Studies . . . . . . . . . . . . . . 37

8.9 The Potential of the Synthesis of Chemicals
from Coal as a DOE Research Program . . . . . . . . . 37

9. Fossil Energy Environmental Project . . . . . . . . . . . 38

9.1 Stored Solids Study . . . . . . . . . . . . . . 38

9.2 Environmental Monitoring Handbook . . . . . . . . . . 38

9.3 Technical Assistance . . . . . . . . . . . . . . 39

9.4 Carryover Activities from FY 1977 . . . . . . . . . . . 39 


\begin{abstract}
This report - the thirty-ninth of a series - is a compendium of month1y progress reports for the ORNL research and development programs that are in support of the increased utilization of coal as a source of clean energy. The projects reported this month include those for coal conversion process development, materials engineering, alkali metal vapor topping cycles, a coal equipment test facility, an AFB coal combustor for cogeneration (CCC), engineering and support studies, process and program assistance, and environmental assessment studies.
\end{abstract}

\title{
1. SUMMARY
}

J. P. Nichols

Highlights of our progress in October are as follows:

- Preliminary material balance results were obtained from hydrocarbonization run HC-23 in which Illinois No. 6 coal (pretreated with $\mathrm{NaOH}$ and $\mathrm{CaO}$ ) was hydrocarbonized at $1060^{\circ} \mathrm{F}$ and 300 psi. Pretreatment of Illinois No. 6 coal with $\mathrm{Na}_{2} \mathrm{CO}_{3}$, in preparation for run $\mathrm{HC}-24$, is progressing on schedule.

- Two blocks of Pittsburgh seam bituminous coal were pyrolyzed under reducing gas in our project in support of in situ gasification. Higher heating rates appear to reduce swelling of the block during pyrolysis, and higher final pyrolysis temperature results in lower boiling tars.

- The final three pressurized residue carbonization tests were completed at $1100^{\circ} \mathrm{F}$ and $400 \mathrm{ps} 1$ of methane with three feed materials:

(1) $100 \%$ vacuum still bottoms (VSB), (2) $50 \%$ VSB and $50 \%$ coal, and

(3) $100 \%$ coal. A final report is being prepared.

- Work is in progress on the fracture toughness of thick sections of steels for piping and pressure vessels in coal conversion plants. Modifications to experimental techniques have been made to allow the heat treatment of $0.394 \mathrm{~T}$ compact tenston specimens. Specimens of A543 Class 1 steel and $21 / 4 \mathrm{Cr}-1$ Mo steel plate have been heat treated to simulate thick plate sections.

- We have selected a list of methods to examine for inspection of CoCrA1Y coatings, and CoCrAlY coating material has been ordered. We have done preliminary calculations for design of an eddy current instrument to measure thickness of CoCrAlY coatings. 
- The first Alloy 20 cladding overlays over Inconel 82 on a carbon steel substrate have been made for several different combinations of welding conditions. Evaluation of the soundness of the deposits is in progress.

- Exposure of heat exchanger tubes in the Fluidyne Corporation atmospheric fluidized bed has reached a maximum of $1500 \mathrm{hr}$. Tube samples have been recovered and are being characterized.

- Failure analysis activities have included examination of samples exposed in the Solar erosion-corrosion experiment, assist.ance with the Wilsonville, Alabama, Solvent Refined Coal Plant for nondestructive examination of plant components, and starting examination of a PERC lock hopper valve.

- In our gas-fired potassium boiler project, three preliminary runs of short duration were made in which the boller was filled with potassium and heated up to or near the boiling temperature with the main burner. Two operating problems were encountered in these runs: (1) It was observed that the argon flow through the nucleators stopped after the system had been filled and run and after draining. Apparently the nucleators are plugging when the system temperature is reduced. The argon flow is reestablished when the system is filled, and the potassium temperature is increased, and a momentary high pressure is applied to the nucleator line. (2) Potassium migrated into the vent lines from the fill tank and the condenser, and plugged small valves in these lines. This is being corrected by increased vapor trapping capacity in these lines.

- A contact has been made with the Memphis Gas, Light and Water Company (MGLW) to obtain detailed process information on the U-Gas process to be used by TRW to develop the components test plan for the MGLW Demonstration Plant.

- ORNL has been requested by DOE-FE to develop a program for testing coa1 feeders currently under development. Jet Propulsion Laboratory (JPL), the coordinator for DOE feeder development, forwarded a data package which included general information, test criteria, and test instrumentation recommended for four coal feeders. This information will be used in a study underway in ORNL to review. the important process parameters for feeder systems required for coal conversion pilot and demonstration plants.

- The second draft of the performance specifications for our AFB coa1 combustor for cogeneration (CCC) project was completed. The specifications were reviewed by the Purchasing Division, and they recommended that the Conceptual Design phase be incorporated into a Proposal phase, and the information desired for the conceptual design be included as a requirement in a Request for Proposal. This is being done, and the first draft of the Request for Proposal will be completed the first week of November. 
- In our project for landfill storage of solid wastes, requests were made for coal and residue samples from all pilot plants proposed for evaluation. Samples of the Slagging Lurgi residue, the residue and feed coal from Westinghouse (Walz Mill), and feed coal for the Hygas pilot plant were received. Contact was made with the Cogas management regarding availability of samples from their facility in England. Design requirements for field scale lysimeters were firmed up and a work order was prepared to cover design costs. 


\section{COAL CONVERSION PROCESS DEVELOPMENT}

H. D. Cochran, Jr.

Coal conversion process development activities are carried out in the Chemical Technical Division. This section discusses hydrocarbonization studies in a 20-atm bench-scale facility, engineering support studies for in situ gasification, and studies of residue carbonization in a pressurized carbonizer.

\subsection{Hydrocarbonization Research}

E. L. Youngblood, J. Beams, and J. C. Rose

\subsubsection{Experimental Development}

Work accomplished. -- The height of the mock-up is being increased by $4 \mathrm{ft}$ to study the fluidization characteristics of a longer reactor. It is planned to increase the length of the bench-scale hydrocarbonization reactor after several runs have been made using treated coal. The mock-up will be used to determine conditions that will give satisfactory fluidization and char circulation in the reactor. A 4-ft-long section has been fabricated from 4-1n.-ID methyl methacrylate for lengthening the mock-up. The mock-up will contain a 65-in.-long draft tube constructed of 1-in.-OD stainless steel tubing.

\subsubsection{Bench-Scale Hydrocarbonization}

Work accomplished. -- During October we continued to treat Illinois No. 6 coal with an aqueous solution of sodium carbonate in preparation for the next hydrocarbonization run. Analytical results and material balance data for run $\mathrm{HC}-23$ are presented in this report.

Treated coal for run HC-24 is being prepared by heating a coal-water slurry containing sodium carbonate in an autoclave to $300^{\circ} \mathrm{C}$. The treatment is being carried out in a batch autoclave using the following procedure. A slurry is prepared by mixing $1.81 \mathrm{~kg}$ of Illinois No. 6 coal $\left(-50+170\right.$ mesh), $0.90 \mathrm{~kg}$ of $\mathrm{Na}_{2} \mathrm{CO}_{3}$, and $7.0 \mathrm{~kg}$ of water. The slurry is loaded into an autocalve and heated to $300^{\circ} \mathrm{C}$ and held at that temperature for $2 \mathrm{hrs}$. After cooling, the coal is washed, filtered, and dried. Thus far about 68 lbs of sodium carbonate treated coal has been prepared. Free Swelling Index measurements indicate that the treated coal has only a slight tendency to agglomerate. Preparation of the feed material for run $\mathrm{HC}-24$ is scheduled to be completed by the end of November.

Analytical data have been received for run $\mathrm{HC}-23$ which was made using Illinois No. 6 coal that had been treated with an aqueous mixture of $\mathrm{CaO}$ and $\mathrm{NaOH}$. The treatment removed approximately two-thirds of the sulfur from the coal but also resulted in a considerable increase in the calcium, sodium and ash content as indicated in Table 2.1. 
Table 2.1. Sulfur and ash content of treated coal

\begin{tabular}{lcc}
\hline & $\begin{array}{c}\text { Illinois No. } 6 \\
\text { coal } \\
\text { (before treatment) }\end{array}$ & $\begin{array}{c}\text { Ilinois No. } 6 \\
\text { coal (after. } \\
\text { Ca0, NaOH treatment) }\end{array}$ \\
\hline \% Organic sulfur & 2.31 & 0.90 \\
\% Total sulfur & 3.86 & 1.38 \\
\% Calcium & 0.94 & 4.55 \\
\% Sodium & 0.09 & 4.46 \\
\% Ash & 12.2 & 23.5 \\
\hline
\end{tabular}

The ofl yield from run HC-23 was $14 \%$ (based on maf coal). The yield is somewhat lower than the maximum yield (21\%) that has been achieved in some of the previous runs using Wyodak coal. It is expected that coal treated with other materials (such as sodium carbonate) may result in higher oil yields. A preliminary material balance, steady state effluent gas analysis, and a summary of experimental conditions for run HC-23 are presented in Tables $2.2,2.3$, and 2.4 .

Work forecast. -- Run HC-24, using Illinois No. 6 coal treated with sodium carbonate, is scheduled to be made around the first of December.

\subsection{Experimental Engineering Support of an In Situ Gasification Process}

J. B. Gibson, P. R. Westmoreland, R. L. Andrews, and L. S. Dickerson

Coal block pyrolysis studies continued during October to support in situ bituminous coal gasification processes. In particular, development of data to support field tests at Morgantown Energy Research Center (MERC) was emphasized. Two bituminous coal blocks were pyrolyzed by the procedure described elsewhere, 1 and the product chars, gases, and tars were analyzed.

Blocks for experiments BP2-23 through BP2-38 have been machined from a Pittsburgh seam bituminous coal supplied by MERC. Other experimenta1 conditions are summarized in Table 2.5. The MERC field test near Pricetown, West Virginia, w111 gasify Pittsburgh seam coal and is planned for August of 1978. Of particular interest to in situ gasification of bituminous coals are tar quantities and qualities. 
Table 2.2. Preliminary material balance for Exp:riment Hz-23

Average bed temperature: $1060^{\circ} \mathrm{F}$

Total pressure: $300 \mathrm{psig} / 230 \mathrm{psig}^{\mathrm{a}}$

\begin{tabular}{|c|c|c|c|c|c|c|c|c|}
\hline & & Mass (g) & $\begin{array}{l}\text { Carbon } \\
\text { fraction }\end{array}$ & $\begin{array}{c}\text { Ash } \\
\text { fraction }\end{array}$ & $\begin{array}{l}\text { Sulf } d r \\
\text { fraction }\end{array}$ & $\begin{array}{l}\text { Percent of } \\
\text { carbon fed }\end{array}$ & $\begin{array}{c}\text { Percent of } \\
\text { ash fed }\end{array}$ & $\begin{array}{l}\text { Percent of } \\
\text { sulfur fed }\end{array}$ \\
\hline Input & . & . & & & & & & \\
\hline $\begin{array}{l}(1) \\
(2) \\
(3)\end{array}$ & $\begin{array}{l}\text { Coal } \\
\text { Scrubber water } \\
\text { Char starter bed }\end{array}$ & $\begin{array}{r}23475 \\
23975 \\
+200\end{array}$ & $\begin{array}{l}.4726 \\
0.0 \\
.8138\end{array}$ & $\begin{array}{l}.2349 \\
0.0 \\
.1417\end{array}$ & $\begin{array}{l}.0119 \\
0.0 \\
.0076\end{array}$ & $\begin{array}{r}79.7 \\
0.0 \\
20.3\end{array}$ & $\begin{array}{r}91.8 \\
0.0 \\
8.2\end{array}$ & $\begin{array}{r}91.4 \\
0.0 \\
8.6\end{array}$ \\
\hline \multicolumn{9}{|l|}{ Output } \\
\hline $\begin{array}{l}(4) \\
(5) \\
(6) \\
(7) \\
(8) \\
(9) \\
(10) \\
(11) \\
(12)\end{array}$ & $\begin{array}{l}\text { Char recovered } \\
\text { Scrubber top (char \& tar) phase } \\
\text { Scrubber middle (aqueous) phase } \\
\text { Scrubber bottom phase } \\
\text { Cold trap top (aqueous) phase } \\
\text { Cold trap bottom phase } \\
\text { Charcoal trap light oil b } \\
\text { Solvent residue } \\
\text { Gases }\end{array}$ & $\begin{array}{r}12793 \\
5790 \\
23750 \\
3308 \\
928 \\
76 \\
526 \\
629 \\
3548\end{array}$ & $\begin{array}{l}.6743 \\
.4550 \\
.0986 \\
.2636 \\
.2636 \\
.80 \\
.7851 \\
.5685\end{array}$ & $\begin{array}{c}.3055 \\
.1861 \\
.0382 \\
.0702 \\
\\
.0702 \\
-- \\
.0189\end{array}$ & $\begin{array}{l}.0156 \\
.0154 \\
.0019 \\
.00172 \\
.00172 \\
-- \\
.0078\end{array}$ & $\begin{array}{r}51.0 \\
18.3 \\
13.9 \\
5.2 \\
0.1 \\
2.5 \\
2.9 \\
12.0\end{array}$ & $\begin{array}{c}54.0 \\
17.3 \\
12.4 \\
3.2 \\
0.1 \\
-- \\
0.2\end{array}$ & $\begin{array}{r}54.0 \\
28.2 \\
12.2 \\
1.5 \\
<.1 \\
-- \\
1.7 \\
2.4^{c}\end{array}$ \\
\hline \multicolumn{9}{|l|}{ Rinses } \\
\hline $\begin{array}{l}(13) \\
(14)\end{array}$ & $\begin{array}{l}\text { Scrubber - water } \\
\text { Scrubber and cold trap - } \\
\text { perchlorethylene }\end{array}$ & $\begin{array}{c}d \\
\underline{53825} \\
\end{array}$ & e & & & - & $\therefore$ & $\longrightarrow$ \\
\hline & Overall balances & 37.6 & & & & 105.9 & 87.2 & 100.0 \\
\hline
\end{tabular}

Reactor pressure was at 300 psig for the first $4 \mathrm{hr}$. of coal Eeed and 280 psig for the remaining 9.3.hr.

${ }^{b}$ Complete aralysis not yet available.

${ }^{C}$ Calculated by difference

$d_{\text {See item } 11 .}$

Not performed. 
Table 2.3. HC-23 effluent gas composition at steady state-300 psig $^{\mathrm{a}}, 1060^{\circ} \mathrm{F}$ at 1645 on $9 / 13 / 77$

\begin{tabular}{cccc}
\hline Component & $\begin{array}{c}\text { Effluent flow } \\
\text { rate (scfm) }\end{array}$ & $\begin{array}{c}\text { Composition } \\
(\%)\end{array}$ & $\begin{array}{c}\mathrm{H}_{2} \text { and } \mathrm{N}_{2} \text {-free } \\
\text { composition (\%) }\end{array}$ \\
\hline $\mathrm{CH}_{4}$ & 0.101 & 0.52 & 49.0 \\
$\mathrm{C}_{2}$ & 0.032 & 0.16 & 15.1 \\
$\mathrm{C}_{3}$ & 0.003 & 0.01 & 0.9 \\
$\mathrm{CO}$ & 0.047 & 0.24 & 22.6 \\
$\mathrm{CO}_{2}$ & 0.004 & 0.02 & 1.9 \\
$\mathrm{H}_{2} \mathrm{~s}$ & 0.021 & 0.11 & -10.4 \\
$\mathrm{H}_{2}$ & 18.505 & 95.40 & - \\
$\mathrm{N}_{2}$ & 0.687 & 3.54 & - \\
\hline
\end{tabular}

${ }^{a}$ System was at 280 psig for part of the experiment. For this condition steady state effluent gas composition was not appreclably different from the above at 300 psig.

${ }^{b}$ Near low limit of sensitivity; accuracy queotionable. 
Table 2.4. Summary of Experiment HC-23 cond1tions and preliminary matertal balances

Bed temperature, ${ }^{\circ} \mathrm{F}$

Reactor pressure, psig

Estimated solids residence time in the reactor, min $300 / 280^{\mathrm{a}}$

Period at steady state, hr

Coal feed ( $\mathrm{CaO}-\mathrm{NaOH}$ treated IIIInois No. 6 coal) Moisture content, wt \%

Ḧydrogen flow rates, scfm

Total hydrogen feed

20.0

Coal transport tube

Draft tube nozzle

$\mathrm{H}_{2} /$ coal feed ratio

$2 \mathrm{~b} \mathrm{H}_{2} / 1 \mathrm{~b}$ coal (maf)

2.2

scf $\mathrm{H}_{2} / 1 \mathrm{~b}$ coal (maf)

413.8

$\mathrm{H}_{2}$ consumed

$2 \mathrm{lb} \mathrm{H}_{2} / 1 \mathrm{~b}$ coal (maf)

$0.03 \pm 0.02$

Carbon balance (\% of carbon fed)

Char

Liquids

Gases

Uvera $\perp 1$

Overall ash balance (\% of ash fed)

Sulfur balance (\% of sulfur fed)

Char

Liyulds

Gases

Overall mass balance (\% of mass charged)

Oil yield (wt \% of maf coal)

${ }^{a}$ Reactor pressure was 300 psig for the first $4.0 \mathrm{hr}$. of coal feed and 280 psig for the remaining $9.3 \mathrm{hr}$.

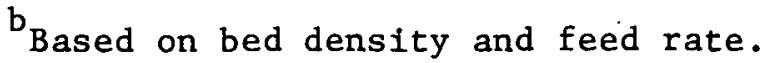

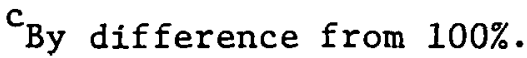


Table 2.5. Summary of experimental conditions for pyrolysis experiments using Pittsburgh seam bituminous coal blocks.

\begin{tabular}{|c|c|c|c|c|c|c|c|c|c|}
\hline \multirow{3}{*}{$\begin{array}{l}\text { Run } \\
\text { number }\end{array}$} & \multirow{3}{*}{$\begin{array}{l}\text { Date of } \\
\text { run }\end{array}$} & \multirow{3}{*}{$\begin{array}{l}\text { Heating } \\
\text { rate } \\
\left(C^{\circ} / \text { min }\right)\end{array}$} & \multirow{3}{*}{$\begin{array}{c}\text { Maximum } \\
\text { temperature } \\
\left({ }^{\circ} \mathrm{C}\right)\end{array}$} & \multicolumn{2}{|r|}{ Cover gas } & \multicolumn{4}{|c|}{ Coal block } \\
\hline & & & & \multirow{2}{*}{ Type } & \multirow{2}{*}{$\begin{array}{c}\text { Flow rate } \\
\text { (Std. liter } / \mathrm{min} \text { ) }\end{array}$} & \multicolumn{2}{|c|}{ Dimensions $(\mathrm{cm})$} & \multicolumn{2}{|c|}{ Weight } \\
\hline & & & & & & Height & Diameter & (kg) & (kg maf) \\
\hline BP2-23 & $1 / 26 / 77$ & 0.3 & 1000 & Argon & 2.99 & 15.2 & 15.2 & $3.550^{\mathrm{a}}$ & 3.289 \\
\hline BP 2-24 & $2 / 11 / 77$ & 3 & 1000 & $\mathrm{Ar}$ & 3.02 & 16.5 & 16.0 & 4.086 & 3.786 \\
\hline BP 2-25 & $2 / 25 / 77$ & 3 & 800 & $\mathrm{Ar}$ & 3.01 & 22.2 & 15.2 & 5.087 & 4.713 \\
\hline BP2-26 & $3 / 15 / 77$ & 0.3 & 1000 & Ar & 3.00 & 19.4 & 15.7 & 4.591 & 4.254 \\
\hline BP 2-27 & $3 / 31 / 77$ & 3 & 600 & Ar & 3.03 & 15.2 & 14.9 & 3.518 & 3.260 \\
\hline BP2-28 & $4 / 21 / 77$ & 0.3 & 600 & Ar & 3.03 & 18.4 & 15.2 & 4.421 & 4.096 \\
\hline BP2-29 & $5 / 31 / 77$ & $3^{b}$ & 600 & Ar & 2.94 & 20.7 & 15.2 & 4.814 & 4.457 \\
\hline BP 2-30 & $6 / 27 / 77$ & 0.3 & 1000 & Ar & 2.93 & 22.2 & 15.2 & 4.857 & 4.497 \\
\hline BP 2-31 & $7 / 13 / 77$ & 0.3 & 800 & $\mathrm{Ar}$ & 2.88 & 15.9 & 16.0 & 4.127 & 3.821 \\
\hline BP2-32 & $7 / 25 / 77$ & 3 & 1000 & $\mathrm{Ar}$ & 2.91 & 16.2 & 15.6 & 4.043 & 3.743 \\
\hline BP 2-33 & $8 / 13 / 77$ & 3 & 640 & $\mathrm{H}_{2}$ & 2.90 & 24.0 & 15.7 & 6.133 & 5.678 \\
\hline BP2-34 & $8 / 31 / 77$ & 3 & 1000 & $\mathrm{H}_{2}$ & 2.95 & 17.8 & 15.2 & 4.564 & 4.226 \\
\hline BP 2-35 & $9 / 21 / 77$ & 3 & 800 & $\mathrm{H}_{2}$ & 2.95 & 21.9 & 15.2 & 5.384 & 4.985 \\
\hline BP $2-36^{\mathrm{C}}$ & $10 / 4 / 77$ & -- & $-\infty$ & $\mathrm{H}_{2}$ & -- & -- & -- & -- & -- \\
\hline BP 2-37 & $10 / 17 / 77$ & 3 & 880 & $\mathrm{H}_{2}$ & 3.08 & 18.4 & 15.1 & 4.217 & 3.904 \\
\hline BP 2-38 & $10 / 31 / 77$ & 14 & 890 & $\mathrm{H}_{2}$ & 2.90 & 19.7 & 15.4 & 4.658 & 4.313 \\
\hline
\end{tabular}

${ }^{\mathrm{a}}$ Coal block dried before heating.

$\mathrm{b}_{\text {Ran }} 85 \mathrm{~min}$ at $6.1 \mathrm{C} / \mathrm{min}$, then $90 \mathrm{~min}$ at $1.9 . \mathrm{C}^{\circ} / \mathrm{min}$.

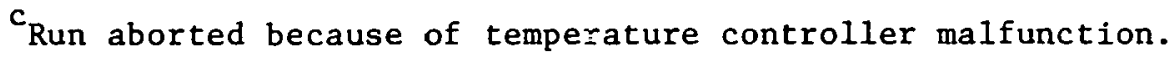


In each October experiment, a $15-\mathrm{cm}-\mathrm{diam}$ coal block was heated to about $900^{\circ} \mathrm{C}$ in a reducing (hydrogen) atmosphere. Heating rates were different: $3 \mathrm{C}^{\circ} / \mathrm{min}$ in experiment BP2-37 and $14 \mathrm{C}^{\circ} / \mathrm{min}$ in BP2-38 (maximum heating rate achievable with this heater). From comparison between these two experiments, differences in char, tar, and gas yields because of heating rates greater than $3 \mathrm{C} / \mathrm{min}$ can be observed.

The most significant early results from BP2-37 and BP2-38 involve physical characteristics of the blocks at differing heating rates. In $0.3 \mathrm{C} / \mathrm{min}$ experiments, blocks had swollen from $15-16 \mathrm{~cm}-\mathrm{diam}$ to touch the 20-cm-diam reactor. By contrast, at $3 \mathrm{C} / \mathrm{min}$ in $\mathrm{BP} 2-37$ and earlier experiments less swelling was apparent, and the block surface was smoother, showing the block surface appeared to have sagged and flowed downward while it was in a plastic state. At $14 \mathrm{C}^{\circ} / \mathrm{min}$, still less swelling was apparent. Also, the block surface was smoother, showing no evidence of surface flow. A common characteristic is that most of the bituminous block pyrolyses have produced blocks with hollowed centers, which are surrounded by an annular region of brittle, flaky char and by a hard, coke-like surface region.

Distillation curves for tar/oil products indicate temperatures at which tar condensation can be expected. These curves may be conveniently generated by a standard gas chromatograph test. Shown in Fig. 2.1-2.3, curves from three $3 \mathrm{C} / \mathrm{min}$ experiments having different maximum temperatures (BP2-33-600 ${ }^{\circ} \mathrm{C}$; BP2-35-800 ${ }^{\circ} \mathrm{C}$; and BP2-34 $-1000^{\circ} \mathrm{C}$ ) may be compared. In general, oil was lighter from the blocks pyrolyzed in higher temperature runs, as may be observed from the cumulative boiling fractions and the maximum boiling points shown in Table 2.6.

Continued testing of bituminous coals in an $\mathrm{H}_{2}$ atmosphere is planned for November. Future experiments will include tests at $0.3 \mathrm{C} / \mathrm{min}$ heated to $600^{\circ}, 800^{\circ}$, and $1000^{\circ} \mathrm{C}$.

Table 2.6. Comparison of tars from bituminous coal block pyrolysis

\begin{tabular}{|c|c|c|c|}
\hline Exper Lmenl: & $\mathrm{DP} 2-33$ & BF2-35 & BP $2-34$ \\
\hline Heating rate $\left(\mathrm{C}^{\circ} / \mathrm{min}\right)$ & 3 & 3 & 3 \\
\hline Maximum temperature $\left({ }^{\circ} \mathrm{C}\right)$ & 600 & 800 & 1000 \\
\hline \multicolumn{4}{|l|}{ Percent boiling at: } \\
\hline $\begin{array}{l}<200^{\circ} \mathrm{C}\left(392^{\circ} \mathrm{F}\right) \\
<300^{\circ} \mathrm{C}\left(572^{\circ} \mathrm{F}\right) \\
<400^{\circ} \mathrm{C}\left(752^{\circ} \mathrm{F}\right) \\
<500^{\circ} \mathrm{C}\left(932^{\circ} \mathrm{F}\right)\end{array}$ & $\begin{array}{l}20 \\
47 \\
72 \\
93\end{array}$ & $\begin{array}{r}11 \\
53 \\
90 \\
100\end{array}$ & $\begin{array}{r}16 \\
55 \\
89 \\
100\end{array}$ \\
\hline Maxtmum boiling point $\left({ }^{\circ} \mathrm{C}\right)$ & 590 & 490 & 440 \\
\hline
\end{tabular}


ORNL DWG 77-2025

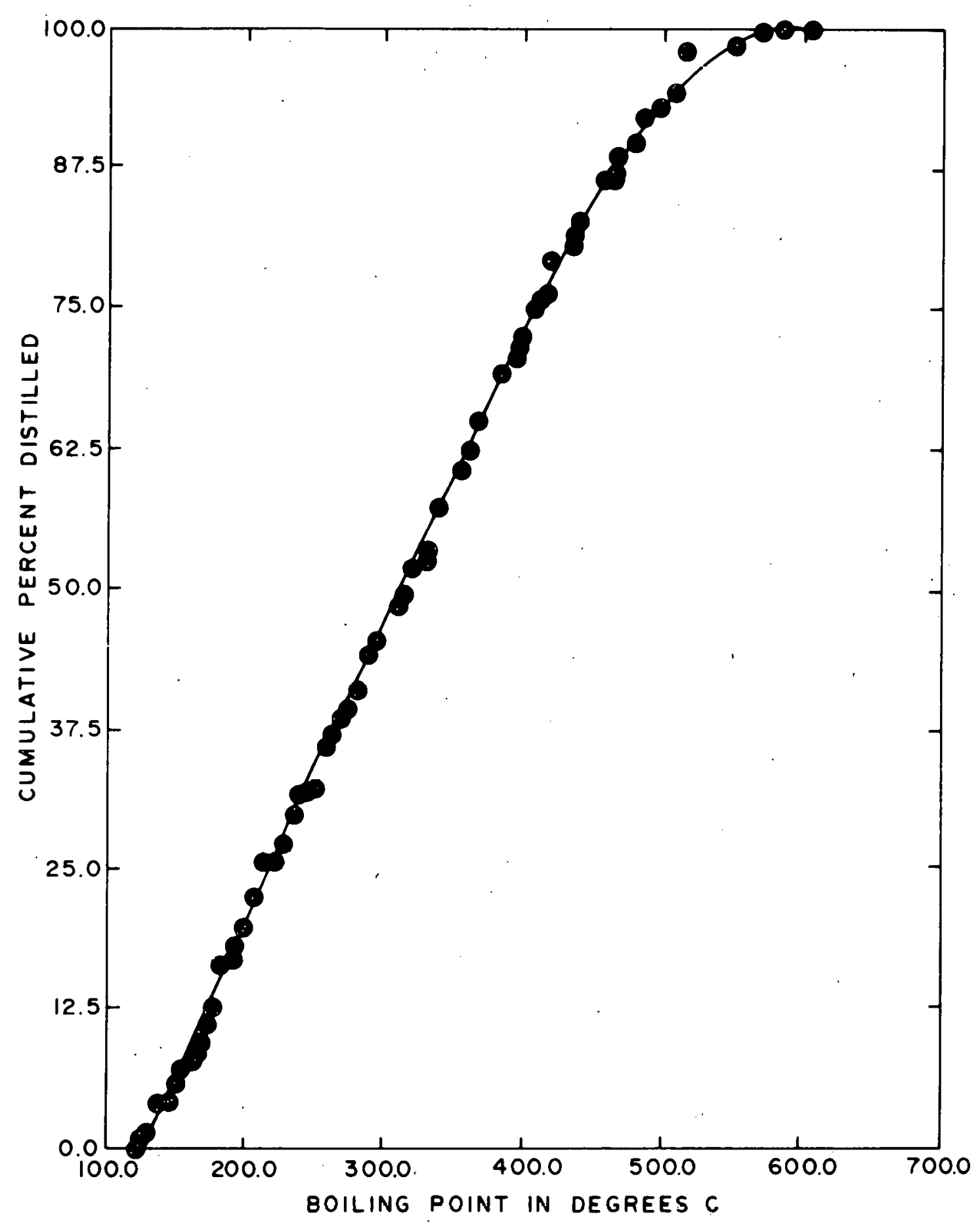

Fig. 2.1. Simulated distillation curve for experiment BP2-33. (Bituminous coal at $3 \mathrm{C}^{\circ} /$ min to $600^{\circ} \mathrm{C}$ with $\mathrm{H}_{2}$ sweep) 


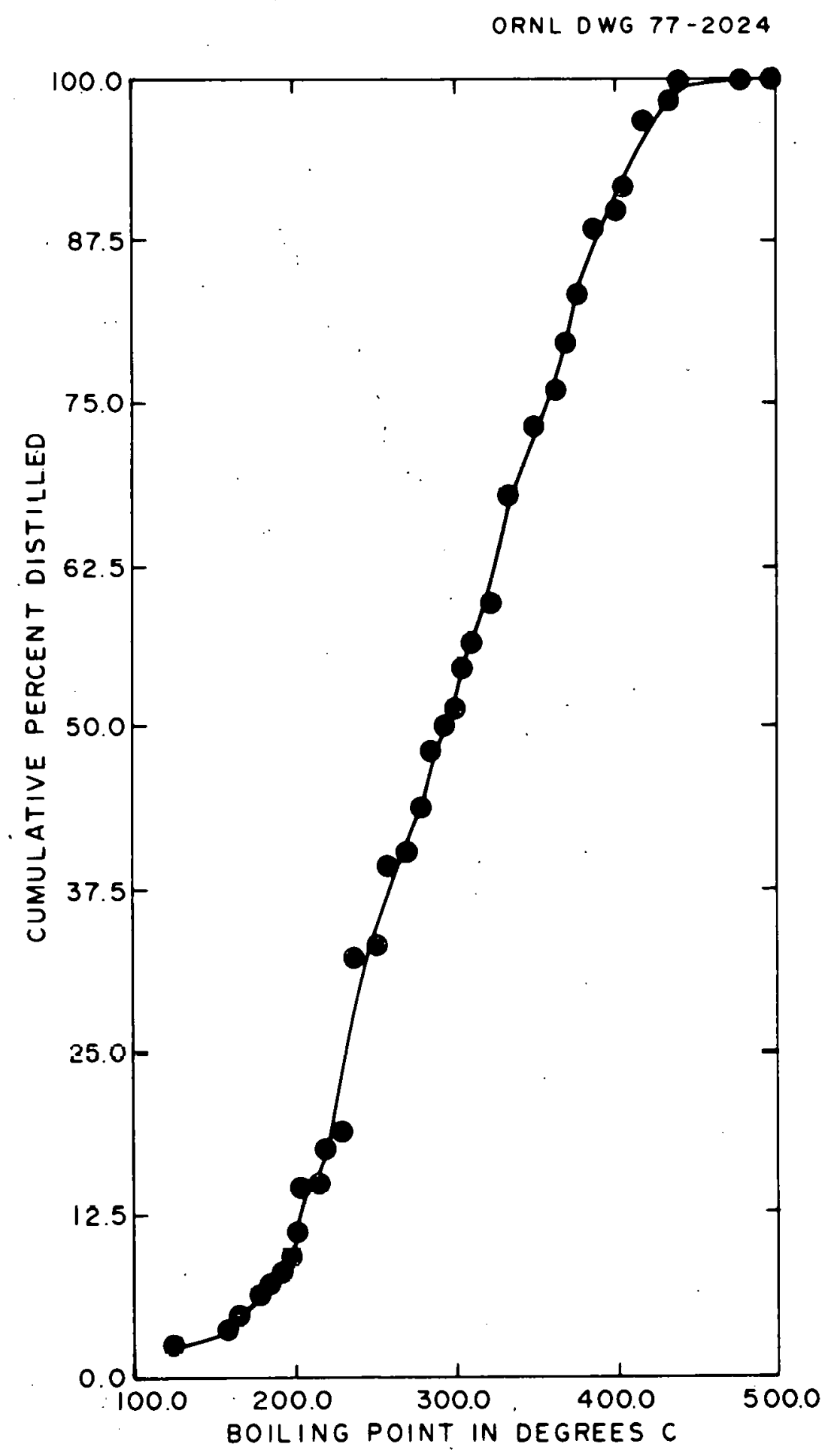

Fig. 2.2. Simulated distillation curve for experiment BP2-35: (Bituminous coal at $3 \mathrm{C}^{\circ} / \mathrm{min}$ to $800^{\circ} \mathrm{C}$ with $\mathrm{H}_{2}$ sweep) 


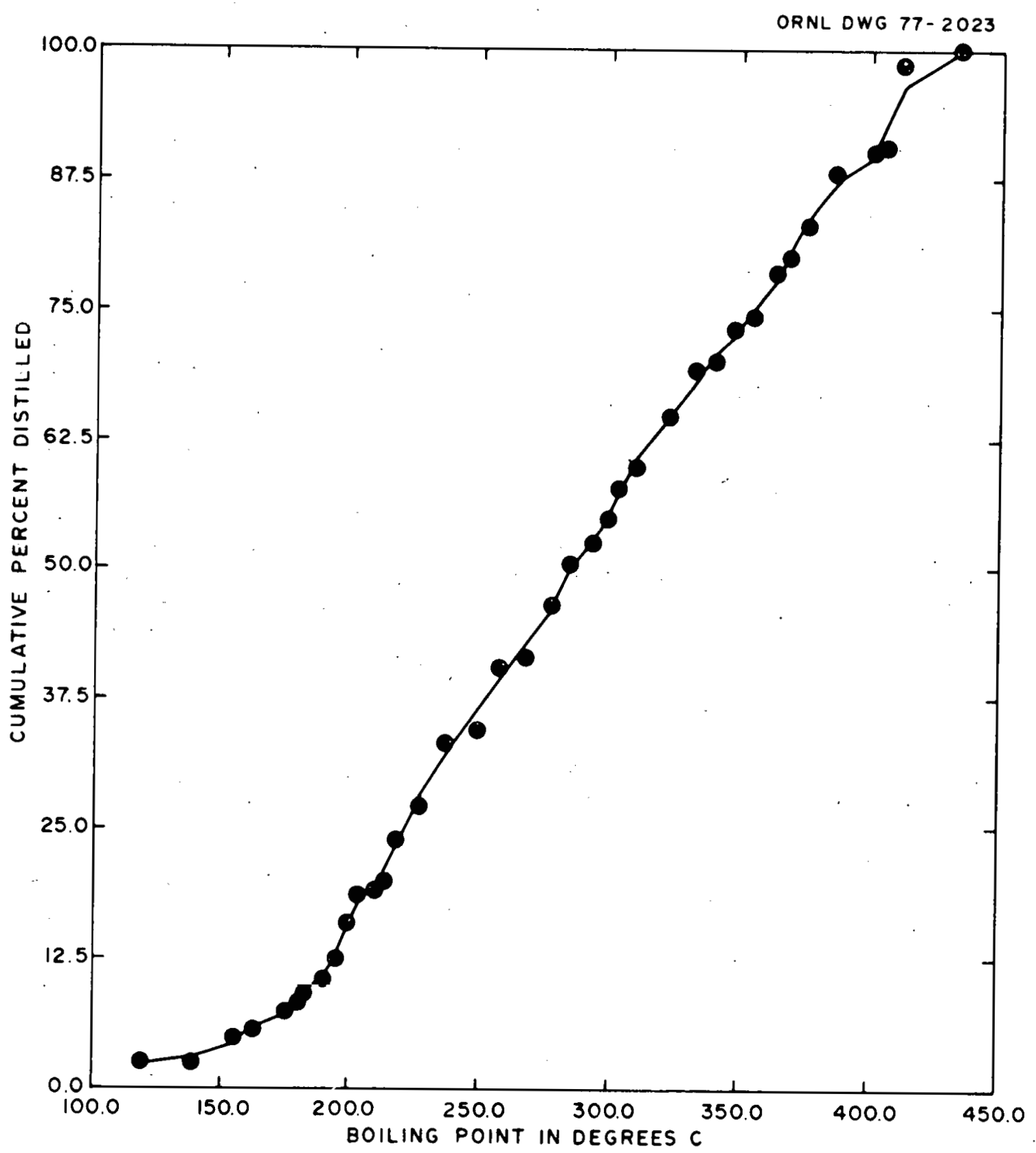

Fig. 2.3. Simulated distillation curve for experiment BP2-34. (Bituminous coal at $3 \mathrm{C}^{\circ} / \mathrm{min}$ to $1000^{\circ} \mathrm{C}$ with $\mathrm{H}_{2}$ sweep) 


\subsection{Pressurized Carbonization of Coal Liquefaction Residue}

R. E. Barker and S. M. Gibson

This project is intended to determine experimentally the degree of coking and liquid degradation to be expected when coal liquefaction residues are carbonized at pressures greater than atmospheric. The experimental apparatus and earlier experiments have been described previously. 2,3

During October the final three experimental runs were made using $\mathrm{H}$-Coal Vacuum Still Bottoms (VSB) and coal (Illinois No. 6) as the feed materials. The conditions of these runs are shown in Table 2.7. Pyrolysis of the VSB and coal produce a much heavier material than was produced in the earlier runs when the feed was the residue and solvent from the Consol Synthetic Fuel process. The viscous material condenses on the condensor tubing and has caused some runs to abort because of plugging in the condenser. The most practical method for recovering the condensed product is to pump solvent through the condensor, evaporate the solvent and analyze the product. It was found that all of the common solvents, pyridine, trichloroethylene, and even acetone were effective for cleaning the condensor. Acetone was used in runs PRC- 29 and PRC-30 because of its high vapor pressure and more acceptable health risk. Though the results with this recovery method are not final, early indications are promising.

As called for in the work plan, a letter outlining results as of October 23 was sent on that date to N. E. Jentz of Ralph M. Parsons Company. Another letter will be sent when more complete results are in hand.

No more experiments are planned in this work; the analysis of the experiments already completed will be finished and reported in future progress and final reports.

\subsection{References for Section 2}

1. J. P. Nichole (ed.), Coal Tcchnology Irogram Annual Iñtei lu Repurt for Fiscal Year Ending June 30, 1976, ORNL-5208 (October 1976).

2. J. P. Nichols (ed.), Coal Technology Program Quarterly Progress Report for the Period Ending June 30, 1977, ORNL-5327 (October 1977).

3. J. P. Nichols (ed.), Coal Technology Program Quarterly Progress Report for the Period Ending September 30, 1977, ORNL-5357 (in preparation). 
Table 2.7. Run conditions for pressurized carbonization of vacuum still bottoms

\begin{tabular}{|c|c|c|c|c|c|c|}
\hline Run & $\begin{array}{c}\text { Pressure } \\
\text { (psig) }\end{array}$ & $\begin{array}{l}\text { Temperature } \\
\left({ }^{\circ} \mathrm{F}\right)\end{array}$ & $\begin{array}{c}\text { Bed } \\
\text { material }\end{array}$ & $\begin{array}{l}\text { Fluidizing } \\
\text { gas }\end{array}$ & Feed $^{a}$ & $\begin{array}{c}\text { Feed wt } \\
\text { (g) }\end{array}$ \\
\hline PRC-28 & 400 & 1100 & Alumina & Methane & $100 \% \operatorname{coal}^{\mathrm{b}}$ & 125 \\
\hline PRC- 29 & 400 & 1100 & Alumina & Methane & $\begin{array}{l}50 \% \operatorname{coal}^{b} \\
50 \% \text { VSB }^{b}\end{array}$ & 118 \\
\hline$P R C-30$ & 400 & 1100 & Alumina & Methane & $100 \%$ VSB & 118 \\
\hline
\end{tabular}

${ }^{a}$ Pulverized to -200 mesh.

${ }^{\mathrm{b}}$ Coal is Illinois No. 6. 


\title{
3. MATERIALS ENGINEERING
}

\author{
R. T. King
}

The materials engineering and associated technology reported here are in support of activities directed by the Materials and Power Generation Branch of the Division of Materials and Exploratory Research, DOE, in the Division of Fossil Energy. Other related work not funded directly by this division of $\mathrm{DOE} / \mathrm{FE}$ is included also.

\section{$\underline{\text { Summary }}$}

Work is in progress on the fracture toughness of thick sections of steels for piping and pressure vessels in coal conversion plants. Modifications to experimental techniques have been made to allow the heat treatment of $0.394 \mathrm{~T}$ compact tension specimens. Specimens of A543 Class 1 steel and $21 / 4 \mathrm{Cr}-1$ Mo steel plate have been heat treated to simulate thick plate sections.

ORNL representatives attended and participated in the First International Conference on Materials for Coal Conversion and Utilization. We have selected a list of methods to examine for inspection of CoCrAlY coatings, and CoCrAIY coating material has been ordered. We have done preliminary calculations for design of an eddy current instrument to measure thickness of CoCrAlY coatings.

The first Alloy 20 cladding overlays over Inconel 82 on a carbon steel substrate have been made for several different combinations of welding conditions. Evaluation of the soundness of the deposits is in progress.

Exposure of heat exchanger tubes in the Fluidyne Corporation atmospheric fluidized bed has reached a maximum of $1500 \mathrm{hr}$. Tube samples have been recovered and are being characterized.

Failure analysis activities have included examination of samples exposed in the Solar erosion-corrosion experiment, assistance with the Wilsonville, Alabama Solvent Refined Coal Plant for nondestructive examination of plant components, and starting examination of a PERC lock hopper valve. 


\subsection{Pressure Vessel and Piping Materials}

D. A. Canonico, W. J. Stelzman, and T. N. Jones

A specimen blank has been designed that measures $31.8 \times 31.8 \mathrm{~mm}$ ( $11 / 4 \times 11 / 4$ in.) for controlled thermal cycling in the DATA TRAK heat treatment facility. Such a blank will permit us to obtain four $0.394 \mathrm{~T}$ compact tension specimens (CTS) from a single furnace run. During the past month we have determined the fastest cooling rate possible with this size blank. The cooling rates varied from $2.5 \mathrm{~K} / \mathrm{sec}$ $(4.5 \mathrm{R} / \mathrm{sec})$ in the center of the $31.8 \mathrm{~mm}$ square specimen blank to $3.0 \mathrm{~K} / \mathrm{sec}$ $(5.5 \mathrm{R} / \mathrm{sec})$ on the surface. This cooling rate simulates that of the surface of 254 to $305 \mathrm{~mm}$ (10 to 12 in.) thick plate. Slower cooling rates representing the $1 / 4$ thickness and mid-thickness locations will also be developed for these $31.8 \mathrm{~mm}$ bars.

We have used the DATA TRAK to heat treat $31.8 \mathrm{~mm}$ bars from the $254 \mathrm{~mm}$ (10 in.) thick plate of A543 Class 1 steel that is under test in the PVT laboratory. These will permit us to compare CTS data obtained from DATA TRAK simulation to material" removed from full size plates.

The DATA TRAK has also been used to simulate the surface cooling rate in 254 to $305 \mathrm{~mm}$ thick $21 / 4 \mathrm{Cr}-1$ Mo steel plate. Two austenitizing temperatures are under investigation, 927 and $1038^{\circ} \mathrm{C}$ ( 1600 and $1900^{\circ} \mathrm{F}$ ). Charpy and tensile specimens will be prepared.

\subsection{Inspection Techniques for Wear- and Process-Resistant Coatings}

R. W. McClung and G. W. Scott

\subsubsection{Review and Evaluation (G. W. Scott)}

G. W. Scott and other ORNL staff members attended the First International Conference on Materials for Coal Conversion Utilization at National Bureau of Standards (NBS), October 11-13. The attention to quality assurance in general and NDT in particular, as reflected by the content of this conference, is minimal. We are concerned that the condition of coated specimens in several erosion or corrosion experiments be characterized by $\mathrm{NDE}$ before placing them in experiments, to facilitate interpretation of results.

We have selected a list of methods to investigate for CoCrAlY coatings. For crack and hole detection, we will consider (I) surface methods, (2) eddy current, and (3) radiography. For one-side coating thickness measurements, we wi.1.] try (1) eddy currents, (2) x-ray fluorescence, and (3) ultrasonics. For detection of unbonds or delaminations, we will 
attempt to use (I) ultrasonic methods, (2) thermographic methods, and (3) electric currents, using a four-point probe. We will concentrate initial efforts on the first method of each sequence; the others will be examined if the preferred method fails to be feasible.

Information gathered thus far indicates that plasma-sprayed CoCrAlY coatings are typically sintered, shot-peened, or hot-pressed to seal the coating layer against corrosive fluids and to densify it. our primary efforts will be applied to inspection of as-sprayed coatings. As resources permit, we will look at coatings produced by one of the secondary methods, the selection of which will be determined by available equipment at ORNL.

\subsubsection{Specimens and Standards (D. P. Edmonds, G. W. Scott)}

Alloy Metals, Inc. (Troy, Michigan), initially identifled as a CoCrAlY supplier, has experienced difficulty in locating a material suitable for our use in their inventory. We declined to place a special order because the minimum batch size includes more material than we expect to use.

In the meantime, we made contact with $\mathrm{R}$. C. Tucker of Union Carbide Linde Division. The Coating Service of Linde. Division also supplies materials and we have placed an order for some UCAR LCO-7, which is Co-23Cr-13Al-0.6Y.

\subsubsection{Thermal Testing (W. A. Simpson, Jr.)}

A thermistor probe for thermal testing of coated samples is being designed. The active element is a $0.13 \mathrm{~mm}(0.005 \mathrm{in}$.) diameter thermistor with a response time of $0.12 \mathrm{sec}$. The difficulty in mounting such a small sensor can be appreciated from the wire size of approximately $0.015 \mathrm{~mm}$ ( $0.0006 \mathrm{in.})$. However, once mounted, the probe should provide adequate sensitivity and resolution in a very small physical package with a low power consumption suitable for field service.

We are also beginning to give consideration to metallic rather than ceramic or cermet coatings. A short computer study is planned to investigate the possibility of inspecting such coatings with thermal techniques.

\subsubsection{Eddy-Current Testing (G.W. Scott)}

To initiate the work on CoCrAlY coatings while awaiting specimens, we made preliminary design calculations for a thickness measuring instrument. From previous measurements on free-standing sprayed metal layers, we estimated a resistivity of $1000 \mathrm{micro-ohm-cm}$. for CoCrAlY and approximated the resistivity of I800 (the substrate) by $100 \mathrm{micro}-0 \mathrm{hm}-\mathrm{cm}$. Design curves indicate that maximum sensitivity to a $10 \%$ thickness change 
require high frequencies and small coils. The maximum frequency that is useful with a reflection-type coil is $20 \mathrm{MHz}$, and the smallest coil available has a mean driver coil radius of .020 in. After we measure the resistivity of the coating (by another technique) we can insert that information into a computer program to optimize and evaluate the sensitivity of the test.

\title{
3.3 Fossil Energy Welding and Cladding Program \\ D. P. Edmonds, J. J. Woodhouse, and J. D. Hudson
}

During this reporting period we have emphasized gas metal-arc (GMA) cladding of carbon steel with Alloy 20 using an intermediate layer of nickel. Carbon steel has been clad with a $0.3 \mathrm{~cm}$-thick layer of Inconel 82 using the GMA process. Alloy 20 deposits have been made over this at nine different sets of conditions, varying the oscillation width from 0.6 to $3.2 \mathrm{~cm}$ and the oscillation speed from 38 to $127 \mathrm{~cm} / \mathrm{min}$. Results from the evaluation of these deposits will be compared to similar GMA deposits made without an intermediate clad layer.

\subsection{Fireside Corrosion of Atmospheric-Fluidized-Bed Combustor Tubes}

\author{
T. G. Godfrey, R. H. Cooper, and J. H. DeVan
}

Sixteen specimen tubes were removed from the FluiDyne atmospheric fluidized bed on October 14 at the conclusion of the 1500-hr test. Some tubes had been removed at intermediate times. Operation of the bed for the final 1000-hr campaign was uneventful. The only difficulty encountered in removing the tubes was that a ring of sintered bed material had locked the tubes in the holes in the refractory wall and had caused the tubes to bow because of the end restraint. Part of the refractory well was ultimately removed during removal of the tubes.

Inspection of the tubes upon their removal revealed a surface different from that seen after $500 \mathrm{hr}$. The tubes showed only minor areas of the polished $\mathrm{CaSO}_{4}$ coating with much of the surface covered by a somewhat grainy coating typical of an oxide film. We saw no evidence of severe pitting or heavy corrosion on any of the tubes.

The sixteen tubes were sealed in plastic bags with a desiccant and returned to ORNL for detailed examination.. Macrophotographs were made of all tubes. Eight of these tubes will be returned to FluiDyne for an additional 3000-hr test in the AFBC; the other eight will be sectioned and examined metallographically for erosion/corrosion effects. Eight new high alloy tubes will replace them in the 3000-hr test together with four $21 / 4 \mathrm{Cr}-1$ Mo steel tubes which will operate at $950^{\circ} \mathrm{F}$. 


\subsubsection{Measurement of Wall Thickness in Test Bed Tubes (G. W. Scott)}

We are exploring nondestructive methods of measuring wall thickness in (nominal) $0.5-i n$. OD tubes which are being prepared for the 3000-hr test in the Fluidyne atmospheric fluidized bed. Eddy currents offer the most accurate method, but we will not be able to assemble an instrument in time. We are looking at various ultrasonic techniques. The objective is to find a method which can measure the wall at any point along the tube, before and after the bed test, to gage metal wastage and locate sites of significant corrosion on the tube ID.

\subsubsection{Atmospheric Fluidized Bed Task Force (J. H. DeVan and T. G. Godfrey)}

The material assessment task for the $200 \mathrm{MW}$ fluidized bed demonstration will be divided between J. H. DeVan and T. G. Godfrey. We are now formalizing our respective assignments with respect to writing and traveling responsibilities. We have also advised members of the Mechanical Properties and Welding and Brazing Groups that their services will be required in this assessment.

T. G. Godfrey has reviewed the Coal Library literature search output (RECON, etc.) and has indicated which documents are desirable from a materials viewpoint. Also, we are generating a bibliography on our hot corrosion information for the Coal Library files.

A literature search has been initiated which, when coupled with telephone contacts, will result in a comprehensive listing of structural materials in existing or retired AFBC's. Included also will be a description of materials tested in FBC's for various applications.

\subsection{Failure Analysis and Prevention}

\subsubsection{Solar* Erosion/Corrosion Coupons (T. G. Godfrey and J. H. DeVan)}

The Solar Corporation test samples described in the previous monthly report have been prepared for metallographic examination. Initial observations show that the surfaces are very complex multi-phase mixtures with major amounts of iron oxides identified by surface x-ray diffraction. A significant observation is that silicates are not found by $x$-ray diffraction, although the abrading coal ash was $\sim 50 \% \mathrm{SiO}_{2}$.

\footnotetext{
*Division of International Harvester Company
} 


\subsubsection{Inspection Assistance to SRC Plant, Wilsonville, Alabama (G. W. $S \cot t)$}

As part of the follow-up to our plant visit at SRC, we sent a letter dated October 5, 1977, documenting our recommendations for their ultrasonic inspections. We received a 347 ss ring (17 in. OD $x 12$ in. ID $x 8$ in. length) machined from the forging which was to become the new lower head for the SRC dissolver tank. The ring was sawed into the sections for a metallographic specimen, mechanical properties specimens, an archive specimen, and an ultrasonic standard. We have since received copies of the report of a nondestructive inspection performed by the forging vendor, which indicates that the forging has "...numerous longitudinal cracks..." and is "...defective beyond repair..." Before proceeding with construction of the ultrasonic standard, we plan to inspect the ring sections with radiography and ultrasonics.

\subsubsection{Liquid Penetrant Inspection of Lock Hopper Valve Ball (S. D. Snyder)}

A ball from a PERC lock hopper valve was checked for microcracking by inspecting the surfaces with Magnaflux Corporation ZL-30A postemulsified fluorescent liquid penetrant. The standard penetrant procedure with a 3-min emulsification was used. No evidence of microcracking was found. However, a pattern of pit-type indications outlining more than half the circumference of the inlet port was observed on the ball where it was exposed to the process slurry when in the closed position. Additionally, several randomly located pit-type indications were also seen on this same surface. 
4. ALKALI METAL VAPOR TOPPING CYCLES

R. S. Holcomb

\subsection{Gas-Fired Potassium Boiler}

R. S. Holcomb, D. B. Lloyd, and R. H. Guyman

\subsubsection{Contract Objective}

Design, construction, and testing of a full-scale potassium boiler tube bundle and burner module on water and then potassium to determine the performance and operating characteristics.

\subsubsection{Status Summary} completed.

1. The detailed checkout of the instrument and control system was

2. The potassium in the fill tank was heated to $1200^{\circ} \mathrm{F}$ to effect oxygen removal with the zirconium foil.

3. The potassium system was evacuated and back filled with argon several times to remove oxygen and water vapor from the system.

4. Three preliminary runs of short duration were made in which the boiler was filled with potassium and heated up to or near the boiling temperature with the main burner. Following each run, the potassium was returned to the drain tank. Steady boiling of the potassium was not established in any of these runs because of their short duration.

5. Two operating problems were encountered in these runs: (1) It was observed that the argon flow through the nucleators stopped after the system had been filled and run and after draining. Apparently the nucleators are plugging when the system temperature is reduced. The argon flow is reestablished when the system is filled, and the potassium temperature is increased, and a momentary high pressure is applied to the nucleator line. (2) Potassium migrated into the vent lines from the fill tank and the condenser, and plugged small valves in these lines. This is being corrected by increased vapor trapping capacity in these lines.

\subsubsection{Plans for Next Month}

The higher capacity vapor trap installed in the condenser vent line and the additional cooling of the vapor trap in the drain tank vent line will be tested in a short shakedown run. When the vapor trapping is satisfactory, additional runs will be made to investigate boiling at low power levels. 


\section{COAL EQUIPMENT TEST PROGRAM}

J. M. Holmes and R. E. MacPherson

The work under the Coal Equipment Test Program (CETP) has been divided into two sections:

- Support for TRW Study

- Coal Feeder Test Program

Progress on these sections during October 1977 is as follows.

\subsection{Support for TRW Study}

TRW Energy Systems started on the1r Critical Components Test and Evaluation Program (UCC-ND Subcontract No. 7410). Negotiations are currently underway with Illinois Coal Gasification Group (ICGG) to obtain proprietary information concerning the COGAS process for the TRW study. However, ICGG has stipulated that ORNL must enter into nondisclosure agreements with ICGG and six of their subcontractors. Since these agreements will require extensive negotiations, ORNL is developing a set of preliminary COGAS process flowsheets and material balances based upon information presented in the open literature. This information will be used by TRW unt1l detailed process data becomes available from ICGG. TRW is developing a data base containing information on component and equipment operations, maintenance and failures in coal conversion and petroleum refinery applications, and metallurgical/corrosion problems encountered in coal conversion systems. Contacts are underway with equipment vendors to obtain detailed information on experience with rotating equipment required for coal conversion facilities.

A contact has been made with the Memphis Gas, Light and Water Company (MGLW) to obtain detailed process information on the U-Gas process to be used by TRW to develop the components test plan for the second DOE Demonstration Plant.

\subsection{Coal Feeder Test Program}

ORNL has been requested by DOE-FE to develop a program for testing coal feeders currently under development. Jet Propulsion Laboratory (JPL), the coordinator for DOE feeder development, forwarded a data package which included general information, test criteria, and test instrumentation recommended for four coal feeders. This information will be used in a study underway in ORNL Engineering to review the important process parameters for feeder systems required for coal conversion pilot and demonstration plants. The study will define the potential areas of application for the feeders specified by JPL. 
Investigation of potential sites for the feeder program is being initiated. A conceptual design of a 5-ton/hr test system will be implemented after selection of the initial feeder to be investigated is made.

\section{AFB COAL COMBUSTOR FOR COGENERATION (CCC)}

R. S. Holcomb

The second draft of the performance specifications was completed. The specifications were reviewed by the Purchasing Division, and they recommended that the Conceptual Design phase be incorporated into a Proposal phase, and the information desired for the conceptual design be included as a requirement in a Request for Proposal. This is being done, and the first draft of the Request for Proposal will be completed. the first week of November.

Walt Saunders, Program Manager for DOE-FE, visited ORNL on October 14 to review the status of the program. The major topics on the agenda were a review of the combustor specifications, status of the assessment study, and a review of project planning activities. Mr. Saunders offered a number of helpful comments on the content and presentation of the specifications during the course of the review. He requested that the Request for Proposal include an appendix that presents much of the data and results on industrial energy needs, and potential coal combustor applications that will be included in the assessment study. This information will help to indicate the potential market for the combustors to prospective suppliers.

In discussing the qualifications of prospective suppliers for the combustor, Mr. Saunders stressed that the primary qualifications of the supplier are that they have experience in fabricating fossil-fired furnaces or boilers and be capable and willing to produce units for future demand.

Work continued on the assessment study. Four sources that present a comprehensive survey of industrial energy needs have been found. These include a study done for EPA, a survey for FEA, a study by the Ford Foundation, and a study done for ERDA on the potential for the use of solar energy in industrial applications. These data sources will be compared and together will serve as a basis for determining the process heat requirements as a function of the temperature level in the process, and thus identify the part of the industrial energy market that is potentially well suited for gas turbine cogeneration systems.

The petroleum and chemical industry have been identifled from the work thus far as having many processes with energy needs that could be met with this system. Certain parts of the processes in the food and paper industries also appear to be attractive for the system. Preliminary analysis of a number of specific processes in the chemical industry has been completed. 
Much of the effort next month w1ll be directed toward compiling the survey data and preparing examples of process applications for the market survey appendix for the Request for Proposal for the combustor.

The request for a Memorandum Directive was approved by ORNL-UCND and submitted to DOE-ORO for approval, where it is. presently under review.

Permission has been given to allow occasional foreign national visitors to visit under escort the test facility if it is located in Building 9731 with no rerouting of the present security fencing. This has led to the recommendation that the facility be located in Building 9731 unless unforeseen difficulties arise. Layout studies for the system in this building have been initiated.

\subsection{Supplemental Studies}

The 1000-hr corrosion test at Fluibyne was completed on 0ctober 12 . The tubes were removed on October 14 with Roy Cooper and Gordon Godfrey of ORNL present. The surface of the tubes had a somewhat different appearance than that observed at the end of the 500-hr test. The calcium sulfate deposit on the tubes was not as hard and shiny as before, but rather it was a rougher surface, and in some spots it had scaled off. The tubes were shipped and have been received at ORNL. Samples will be cut from the tubes for polishing and metallographic examination and analysis. 


\title{
7. ENGINEERING STUDIES AND TECHNICAL SUPPORT
}

\author{
J. R. McWherter
}

\subsection{Process Modeling}

R. Salmon and D. M. Lister

\subsubsection{Contract Objective}

The objective is to assist the Fossil Energy (FE) Major Facility Project Management Division of DOE in its plan for computer analysis and computer support for coal conversion studies. This includes assistance to Purdue and Lehigh Untversities in the development of computer programs for this plan.

\subsubsection{Status Summary}

a. A meeting of DOE, Purdue, Lehigh, and ORNL representatives was held in Washington, D.C. on October 19. Progress on the project was reviewed. The modifled process flow diagram for the ICGG process developed by Purdue was discussed.

b. Work on the HDC heat exchanger design and cost program continued. A number of example cases were run to obtain cost comparisons between $\mathrm{HDC}$ and other sources of cost information. HDC agreed very well with the costs published by Fanaritis and Bevevino of Struthers-Wells (Chem. Eng., July 1976). The average difference in eight examples was $2.5 \%$. Agreement with the Richardson method also was good. The Icarus COST program and the Guthrie method (escalated from 1970 data) gave much higher costs, generally about $20 \%-60 \%$ higher. The escalated Guthrie costs were considerably higher than those given by COST.

Additional vendor estimates are belng sought to help resolve some of the differences noted.

c. Work continued on the installation of the Purdue material balance and physical properties routines on the ORNL IBM computer system. The Purdue routines are being edited to remove incompatibilities between the CDC Fortran used by Purdue and the Fortran compiler used by the IBM system. 


\subsection{Synthetic Fuels Process Research Digest}

R. W. Glass and F. M. O'Hara

\subsubsection{Cühtract Objective}

The objective is to provide continuing technical assistance to the Assistant Director for Processes of the Division of Materials and Exploratory Research (DMER) by preparing digest reviews of current or potential subjects relating to coal conversion technology.

\subsubsection{Status Summary}

a. Final review copies of the last three articles for the first issue were received back from contractors and DOE/FE revlewers. Changes requested by the reviewers were made; one of these changes was substantive and reflected increased knowledge above the subject matter generated since the original writing of the article. A distribution list was compiled and approved by Laboratory and DOE-Headquarters personnel. The cover and front matter were finalized and approved. Production of the final mats for printing is awaiting resolution of one, last question of copyright clearance.

b. Of the four articles to be written for the second issue, one (on Consol's CSF process) has gone through internal editorial review and has been accordingly revised. The second (on SRCII) is being rewritten to reflect a large amount of information about the project just recently disclosed in journals and at scientific meetings. The others (on Fischer-Tropsch and on conversion of coal to low-Btu gas) are being researched.

\subsection{Survey of Industrial Coal Conversion Equipment Capabilitles}

R. W. Glass, J. M. Holmes, J. R. Horton, M. Siman-Tov,

W. R. Williams, W. A. Bush, E. C. Slade, J. P. Meyer, M. S. Edwards, W. R. Gambill, and W. R. Reed

\subsubsection{Contract Objective}

The general objective of this project is to conduct surveys of industrial equipment capabilities that will identify the present capability of industry to supply the equipment needed. The project will also determine research and development needs, including lead time requirements, for producing equipment of advanced design for the various unit operations of critical importance to the Major Facility Project Management Division's (MFPM) programs. 


\subsubsection{Status Summary}

Meetings were held this reporting period at ORNL with Mr. T. K. Lau, Project Manager, DOE/FE, in order to (1) review the ORNL survey presentations to be held soon in Washington, and (2) discuss the development of FY-78 tasks for the industrial survey project. Each of the survey presentations (rotating components, valves, hot gas cleanup equipment, and heat recovery equipment) was well received. Handouts, agenda, and other miscellaneous mechanical items important to the review program were addressed. The entire presentation program is scheduled for November 29 in Washington. Preliminary work statements under development for FY-78 survey work include (1) the preparation of final reports (reviews in progress) for FY-77 surveys, (2) general continuation of the 77 valve survey to include additional important valve types as a complimentary survey, (3) reliability and operating experience of selected industrial equipment. Other and/or additional tasks will be formalized soon.

\subsection{Support of Initial Operations}

B. Niemann and T. W. Pickel

?

On October 26, ORNL personnel attended a meeting with DOE-Fossil Energy Initial Operations Group to clarify the Task Assignment. The Task Assignment basically consists of a rapid 14-day turnaround review and analysis of DOE provided documents on contracted coal conversion demonstration plants, a continuing effort for the preparation of procedures and checklists for the above, and the preparation of guidelines for certain manuals. The Initial Operations Group, headed by Hershul Jones, is primarily concerned with operability of the demonstration plants. The following topics were discussed:

1. The type of design documents to be reviewed

2. The present Demo Plant Contracts and their status

3. DOE-Initial Operations Interface with DOE Project Direction

4. Availability of background information for Demo projects

5. Means for ORNL to stay current on Project's progress

6. Work split and interface between ORNL and Argonne (the other reviewer organization for Initial Operations)

7. DOE expected review and analysis output documentation

A team composed of three personnel from Engineering Division and one from Chemical Technology Division has been selected and has begun work on this task: 
The first effort is being directed towards writing a work plan and schedule, and beginning the procedures and checklists preparation effort to get ready for a rapid review request.

\subsection{Flash Hydropyrolysis}

S. P. N. Singh

\subsubsection{Contract Objective}

The objectives are to perform a scoping study on two conceptual flash hydropyrolysis processes and to determine if a more detailed engineering evaluation of one of these processes is justified.

\subsubsection{Status Summary}

Comments on the draft of the final report have been received from DOE and are now being considered for incorporation.

\subsection{Hot Gas Purification Processes \\ M. S. Edwards and J. P. Meyer}

\subsubsection{Contract Objective}

The objective of this profect is to investigate the present stateof-the-art hot gas cleanup processes. The application of most interest is the removal of contaminants (i.e., particulates, sulfurous gases, alkali metals, etc.) from coal-derived fuel gas prior to firing combined cycle turbines.

\subsubsection{Status Summary}

During the reporting interval, the following work has been completed:

a. Revised estimates of system performance have been prepared for a number of different cleanup configurations using particle size distribution data obtained at the Exxon PFBC miniplant.

b. Information has been obtained on non-conventional cleanup technologies. These include:

- Particle Precipitating Heat Transfer Surface

- Molten Glass Scrubber.

c. An analysis of the alkali metal problem has been undertaken. Emphasis has been placed on ascertaining information on turbine tolerances for alkali compounds and on quantifying the potential for alkali release from coal. 
d. The question of $\mathrm{NO}_{\mathrm{x}}$ control in high temperature systems is being addressed. Several mechanisms of $\mathrm{NO}_{x}$ formation and various methods of control complicate this evaluation.

e. A tentative outline for the final report has been drafted. Topics to be covered will include:

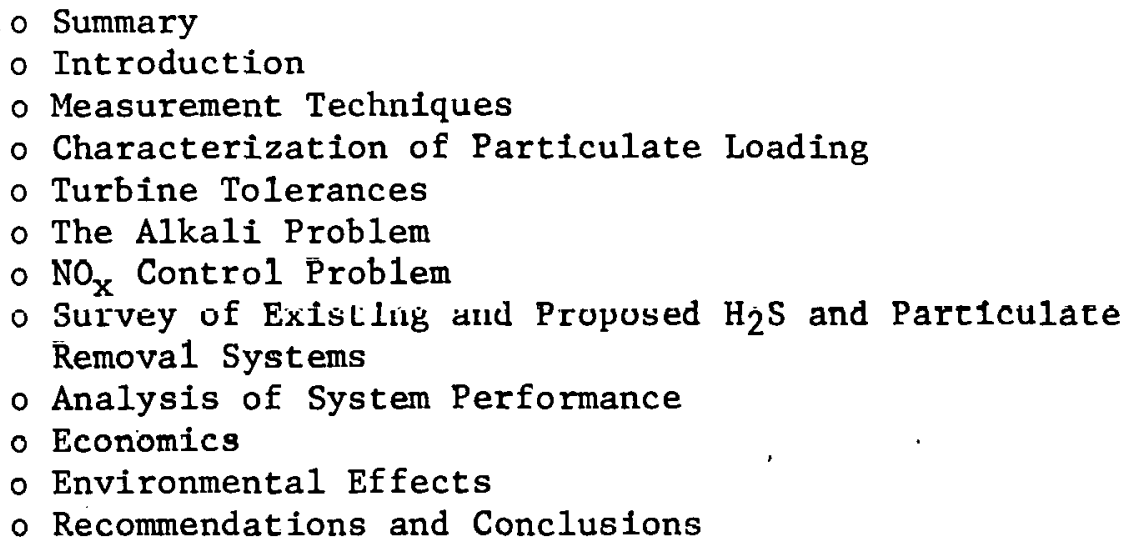

\subsection{State-of-the-Art Review of Heat Recovery Processes}

W. R. Gambill

\subsubsection{Contract Objective}

The objective of this review is to survey, appraise, and catalog the processes for heat recovery which industry offers or plans to offer or may logically be expected to offer. These processes will be applicable to the recovery of heat in process streams from primary exothermic coal conversion and combustion process sțeps, Simple unaugmented appliration of conventional heat transfer equipment will not be included. The review will distinguish between presently installable technology, near term developable technology, and future prospects. Consideration will be given to possible transfer of technology from other industries.

\subsubsection{Status Summary}

a. Information was acquired concerning several items of probable interest. C-E Lummus (Heat Transfer Div.), e.g., can provide heat exchanger degigno uaing Union Garbide's Iligh-Tlux Tiliting, which is costly but exhibits an overall coefficient for phase change applications (evaporation/condensation) about five times higher than smooth tubing. For equal performance, the cost of a complete exchanger with High-Flux Tubing is apparently within $\pm 20 \%$ of the cost of a smooth-tube unit.

b. The Ozaki quench cooler, patented in Japan, is soon to undergo prototype testing. Employed in Union Carbide's crude-oil 
cracking process, the cooler is claimed to prevent coking on the tube side of waste heat firetube boilers by causing quenching oil to flow on the inner wall surfaces. Gas from the cracking process might be cooled, e.g., from $1650^{\circ} \mathrm{F}$ to $750^{\circ} \mathrm{F}$ while generating steam at $600-1400$ psia. A thin oil film is maintained by high hot-gas velocities (65-165 $\mathrm{fps}_{\mathrm{p}}$ ).

c. A computer system has been developed (T. B. Challand, OGJ, Sept. 6,1976 ) to assist in optimizing the design of heat exchanger networks. Interesting conclusions from work to date include:

- Complex exchanger networks, with high heat-recovery levels, are generally less sensitive to changes in process operating conditions than systems with lower levels of heat recovery.

- At high heat-recovery levels, the cost of an exchanger network is little affected by its configuration.

- For even a simple network Involving two hot and two cold streams, it has been shown that over 200 exchanger networks could meet the requirements.

d. She11 011 Company is installing a 1.5-mile-long closed waste heat loop at a large $(240,000$ BPD) refinery in Louisiana. Refined kerosene w111 be used to absorb heat from 10-12 sources, mainly $800^{\circ} \mathrm{F}$ flue gas, and transfer it in exchangers to preheat boiler feedwater and to provide reboiler heat to a process unit. The kerosene will be circulated at a rate of 3940 gpm between high and low temperatures of $417^{\circ} \mathrm{F}$ and $210^{\circ} \mathrm{F}$. Heat savings will total about 4.8 billion Btu/day.

\subsection{Assessment of a Moving Bed System for Cleanup of Raw Gasifier Gas}

R. W. G]ass, W. R. Gambill, and R. H. Lamb*

\subsubsection{Contract Objective}

The objective is to evaluate the feasibility of a proposed moving bed system for recovery of heat and removal of sulfur and particulates from raw gasifier gas.

\subsubsection{Status Summary}

a. Comments on the project draft report are being considered.

b. Preparations for a project review. for November 7, 1977, are in progress.

\footnotetext{
*Consultant.
} 
7.9 Technical/Economic Assessment of Hydrogen Production by the Steam/Molten Iron Process

R. W. Glass and L. Seglin*

\subsubsection{Contract Objective}

The objective is to determine if there is sufficient incentive to develop the subject process for production of hydrogen from coal.

\subsubsection{Status Summary}

a. Tasks 1,2 , and 3 are $100 \%$ complete.

b. Task 4 is about $90 \%$ complete.

c. Task 5 is about $40 \%$ complete.

d. Task 6 is about $10 \%$ complete.

e. Task 7 has been started. Data from Ralph M. Parsons have been received and reviewed. These data are not complete enough to enable a comparison with the subject process, and additional data have been requested of DOE.

\subsubsection{Problem Areas}

Establishment of a proper basis of comparing the economics of this process with those for alternate processes has not been resolved. Efforts will be made to use the RMP - data from their SRC-II study. But this may not be possible from the available data.

\subsubsection{Supporting Data}

These will be presented and reviewed at the next meeting at ORNL with DOE and ORNL.

\subsection{A Study of Effluent Control Technologies for Hydrocarbon and Carbon Monoxide Emissions from Coal Conversion Plants}

\section{Fisher and 6. Patereon}

\subsubsection{Contract Objective}

The objective of this project is to provide a technical and economic comparison of processes available for the control of gaseous hydrocarbon (HC) and carbon monoxide ( $\mathrm{CO}$ ) emissions. The Lurgi gasification process 
and the HCOAL liquefaction process will be considered as reference source systems, and comparisons of control technologies will consider incineration as the reference control system.

\subsection{0 .2 Status Summary}

a. No formal written report was required for this work. Notes, figures, data, etc., have been collected and summarized. The collection is presently receiving staff review. If no formal request is received a staff report will be issued as an ORNL CF Memo.

b. Incineration is the most economic route for the removal of $\mathrm{C}_{2}+$ hydrocarbon and $\mathrm{Co}$, In total about $2 \%$, from the Lurgi SNG Process waste gas streams. Incineration in a coal-fired boiler or over a catalyst bed are the most economic routes. The base case, incineration in a syngas-fired boiler costs at least twice as much. All other routes cost several times as much as the latter route.

c. Neither incineration in a coal-fired boiler nor over a catalyst bed have been carried out under conditions closely approximating those proposed in this study. Some development work will be necessary in either case.

d. Operating costs are about $5 \notin$ per Mscf of SNG for incineration in the coal-fired boiler or over a catalyst bed and about $11 \not$ for incineration in a syngas-fired boiler.

\subsubsection{Changes}

The subject work officially ended September 30, 1977. The present reporting is a final summary of our FY 1977 effort.

\subsection{0 .4 Open Items}

No guidance has been received regarding further work on this study. 


\section{PROCESS AND PROGRAM ANALYSIS}

J. R. McWherter

Process and program analysis studies are being conducted for the DOE Fossil Energy Office of Program Planning and Analysis. This effort includes research studies on most of the coal conversion and utilization processes. The program objective is to provide, on a consistent basis, technical and economic evaluations of competing processes and systems for coal conversion and utilization.

\subsection{Luw Btu Coal Gasification}

H. F. Hartman, D. E. Reagan, and J. P. Belk

The draft report on the Low Btu Coal Gasification Study was distributed for review and comment. The report summarized the work done from July 1976 through September 1977 and included the following sections: abstract, introduction and summary, screening and selection, process data, process comparisons, and process considerations. Complete copies of the report draft were distributed to ORNL personnel and to Dr. L. M. Joseph, Department of Energy project manager, for their comments.

Specific process data subsections were mailed to the process proponents for their review. Eleven of the twenty-one process subsections were sent to personnel in the Department of Energy, Fossil Energy Gasification who manage the DOE-supported projects. The remaining 10 subsections were mailed directly to industry representatives. Comments received from the ORNL and process reviewers will be considered in preparing the final report. Several sets of comments have been received including those f.rnm Dr. Joseph of DOE.

\subsection{Direct Combustion}

E. C. Fox, T. D. Anderson, and H. I. Bowers

\subsubsection{Objectives}

The purpose of this study program is to assist DOE/FE in their effort to develop a national strategy to increase the near-term use of coal through direct combustion; the applications of interest in this study are the smal1-to-moderate industrial user and the large residential/commercial user. The following objectives will be accomplished:

1. Identify and quantify the important factors restricting the use of coal in the sectors of interest.

2. Evaluate potential technological and institutional solutions to the problems identified in (1) above. 
3. Make recommendations to $\mathrm{DOE} / \mathrm{FE}$ relative to the most promising approaches to increasing the near-term use of coal.

\subsubsection{Status Summary}

Most of the month was spent preparing the interim report on the Assessment of Barriers to the Increased Coal Use in Industry and for the Residential/Commercial Sector. The report is in a draft form and is being forwarded to DOE for review and comments.

Some effort has been made to gather data concerning the possible technical alternatives: central steam generation, coal depots, etc. Further analysis of these concepts will be conducted in the following months.

\subsection{Advanced Power Conversion Systems}

All twelve reports covering this work were completed and sent to OPPA for review before September. No additional work was done in October on this profect.

\subsection{Liquefaction}

The Ralph M. Parsons Company is working under subcontract on this subprogram with J. B. O'Hara as Project Manager.

\subsubsection{Detailed Review of High Potential Liquefaction Processes}

8.4.1.1 Objective. The objective is to perform detailed process, technological, and economic analyses of high potential liquefaction processes.

8.4.1.2 Activity Summary. Process descriptions, flow diagrams, and fixed capital investment estimates are being prepared for the shortlisted processes.

The flow diagrams being developed include product upgrading to produce marketable fuels.

Parsons completed basic process design and fixed capital investment information for economic analyses of the Fischer-Tropsch Flame Sprayed Catalyst and M-Gasoline processes.

Parsons developed preliminary economics for conversion of $\mathrm{H}$-Coal syncrude produst to market products. This was in response to a special request from the Department of Energy.

\subsubsection{Establish Uniform Economic Comparison Basis}

8.4.2.1 Objective. The objective is to provide techniques for economic comparison of the most viable processes on a uniform basis for the detailed process analyses. 
8.4.2.2 Activity Summary. Parsons completed logistics transport study from the three selected plant sites to four major marketing areas. One short listed process was selected as representative.

Parsons established the computer program for economic analysis.

\subsection{High Btu Gas}

This subprogram is being analyzed under subcontract by the Scientific Design Company, Incorporated (SD) with A. S. West as Project Manager.

\subsubsection{Contract Objectives}

The objective of the work is to provide technical and economic evaluations of competing processes, concepts, and systems for the production of high Btu gas from coal.

\subsubsection{Status Summary}

The final report on the Battelle Agglomerating Ash Burner Process Evaluation (High Btu) has been reviewed. A study of this process for medium Btu gas production is being initiated. Preliminary heat and material balance and other technical information prepared by Battelle was reviewed by SD. Preliminary agreement was reached on a design basis for the additional evaluation. Battelle has agreed to provide some additional data to back up some of the remaining points.

\subsection{In Situ Coal Gasification \\ W. C. U1rich}

\subsubsection{Cunlrace Object1ve}

The objective of this program is to provide technfcal and economic evaluations of candidate processes for the conversion of coal in situ to. fluid products presently of interest.

\section{6 .2 Status Summary}

a. Draft copies of the final report, "Process Designs and Economic Evaluations for the Linked Vertiral Well In Situ Coal Gasification Process," were submitted to OPPA and others for review and comment.

b. Two members of the evaluation team met with representatives of the DOE Denver Project Office, Laramie Energy Research Center, and Lawrence Livermore Laboratory. The purposes of the meetings were (1) to discuss the draft report mentioned above, (2) to visit LERC and LLL field test sites at Hanna, and Gillette, Wyoming, respectively, and (3) to learn the current status of the steeply dipping bed project which is being monitored by DPO. 
c. A preliminary work statement which outlines a systems analysis study of in situ coal gasification plants to be carried out in FY 1978 was prepared and submitted.

\subsection{Coal Beneficiation}

G. R. Peterson and S. P. N. Singh

\subsubsection{Contract Objective}

The objective of this project is to provide technical and economic evaluations of current beneficiation processes.

\subsubsection{Status Summary}

The draft of the final report on coal beneficiation has been completed. It is presently being typed and readied for transmittal and review.

\subsection{Gas Cleanup Studies}

M. S. Edwards

\subsubsection{Contract Objective}

The objective of the gas cleanup study is to collect information on the technology and economics of processes for the removal of impurities (principally hydrogen sulfide) from fuel gas streams: High- and lowtemperature cleanup processes will be reviewed.

\subsubsection{Status Summary}

a. A draft report covering the FY 1977 work was submitted to DOE last month.

b, New tasks are being developed for gas cleanup studies in FY 1978.

\subsection{The Potential of the Synthesis of Chemicals from Coal as a DOE Research Program}

This work is being done under subcontract by the Radian Corporation with D. N. Garner as the Project Director.

The final draft report was completed and submitted to ORNL and DOE/ FE-OPPA for review. 


\title{
9. FOSSIL ENERGY ENVIRONMENTAL PROJECT
}

\author{
C. R. Boston
}

\subsection{Stored Solids Study}

W. J. Boegly, Jr.

Requests were made for coal and residue samples from all pilot plants proposed for evaluation. Samples of the Slagging Lurgi residue, the residue and feed coal from Westinghouse (Walz Mill), and feed coal for the Hygas pilot plant were received. Contact was made with the Cogas management regarding availability of samples from their facility in England. Discussions were held with the ORNL traffic department about the logistics and packing requirements for air shipment of residues and coal from England and Scotland. Design requirements for field scale lysimeters were firmed up and a work order was prepared to cover design costs.

Staffing for this task was completed this month and a revised and expanded FY 1978 Program Plan was delivered to DOE.

\subsection{Environmental Mon1toring Handbook}

\section{S. G. DeCicco}

The Handbook is now being used extensively by contractors and their environmental subcontractors in designing monitoring programs for the nation's first fossil demonstration plants (pipeline gas). This has become an extremely important position document in our role as advisors to the contractors in developing the ER's and ultimately in our role as aithors of the EIS's.

During the month of October, several authors began revising their sections of the Handbook. Close contact was maintained with DOE, Radian Corporation, Fossil Energy Environmental Project members, and the Technical Editing Department so that the completion of the revised Handbook could proceed smoothly. On October 25, S. G. DeCicco visited Radian Corporation's office in McLean, Virginia, and met with Stan Dzierlenga to discuss the contents and format of the process monitoring section. We are still on schedule for our contribution. However, we estimate that Radian's rough draft wl11 not be avallable before mid-December. 


\subsection{Technical Assistance}

\subsubsection{Interaction with Demonstration Plant Contractors (S. G. DeCicco)}

A revision to ICGG's geohydrology program required a trip to Illinois by Don Lee and S. G. DeCicco on October 12, 1977, to meet with ICGG, Gibbs and Hill, the Illinois State Geologic Survey, and the Illinois Water Survey to discuss the program requirements.

In addition, the team worked on developing a rather detailed cost estimate for the CONOCO environmental monitoring program and environmental report. On October 18, 1977, representatives from Westinghouse Environmental Systems Department visited ORNL to compare independently derived cost estimates. On October 25, 1977, S. G. DeCicco presented ORNL's cost estimate to Hershul Jones (DOE) in Washington.

\subsection{Carryover Activities from FY 1977}

9.4.1 Environmental and Health Aspects of Disposal of Solid Wastes from Coa1 Conversion: An Information Assessment (H. M. Braunstein)

This document is receiving final in-house review and is scheduled to go to the printer on December 1, 1977. 


\section{THIS PAGE \\ WAS INTENTIONALLY \\ LEFT BLANK}


INTERNAL DISTRIBUTION

\author{
1. S. I. Auerbach \\ 2. M. Bender \\ 3. N. E. Bolton \\ 4. C. R. Boston \\ 5. C. H. Brown \\ 6. G. H. Burger \\ 7. D. A. Canonico \\ 8. J. A. Carter \\ 9. B. R. Clark \\ 10. H. D. Cochran, Jr. \\ 11. E. Copenhaver \\ 12. K. E. Cowser \\ 13. R. M. Davis \\ 14. V. A. DeCar1o \\ 15. D. G. Doherty \\ 16. M. S. Edwards \\ 17. J. L. Epler \\ 18. D. E. Ferguson \\ 19. L. M. Ferris \\ 20. R. C. Forrester III \\ 21. W. Fulkerson \\ 22. E. L. Fuller \\ 23. W. R. Gambi11 \\ 24. R. B. Gammage \\ 25. D. A. Gardiner \\ 26. C. W. Gehrs \\ 27. R. W. Glass \\ 28. T. G. Godfrey \\ 29. W. L. Greenstreet \\ 30. M. R. Guerin \\ 31. C. W. Hancher \\ 32. L. A. Harris \\ 33. S. E. Herbes \\ 34. J. R. Hightower \\ 35. R. S. Holcomb \\ 36. J. M. Holland \\ 37. J. M. Holmes \\ 38. J. K. Huffstetler \\ 39. G. R. Jasny, Y-12 \\ 40. R. L. Jolley \\ 41. J. E. Jones, Jr. \\ 42. 0. L. Keller \\ 43. R. T. King \\ 44. W. R. Laing \\ 45. R. S. Livingston \\ 46. R. E. MacPherson \\ 47. A. P. Malinauskas \\ 48. G. B. Marrow \\ 49. C. J. Mchargue
}

50-55. L. E. McNeese

56. J. R. McWherter

57. H. J. MeL.

58. J. E. Mrochek

59. P. Nettesheim

60. J. P. Nichols

61. B. Niemann

62. L. C. Oakes

63. G. R. Peterson

64-65. T. W. Pickel

66. H. Postma

67. D. E. Reichle

68. C. R. Richmond

69. B. R. Rodgers

70. M. W. Rosentha1

71. R. H. Ross

72. T. H. Row

73. W. L. Russe11

74. R. Salmon

75. G. Samuels

76. C. D. Scott

77. D. S. Shriner

78. W. D. Shults

79. S. P. N. Singh

80. C. B. Smith

81. G. P. Smith

82. I. Spiewak

83. R. L. Spore

84. J. B. Storer

85. R. A. Strehlow

86. H. E. Trammel1

87. D. B. Trauger

88. W. C. Ulrich

89. P. R. Vanstrum

90. J. S. Watson

91. J. R. Weir

92. P. R. Westmoreland

93. L. V. Wilson

94. C. S. Yust

95. S. Alpert (Consultant)

96. H. Beuther (Consultant)

97. M. Semchyshen (Consultant)

98. H. W. Sternberg (Consultant)

99. C. Streed (Consultant)

100. Patent Office

101. Lab. Records-RC

102-107. Lab. Records

108-110. Central Research Library

111. Document Reference Section 
EXTERNAL DISTRIBUTION

DOE-Oak Ridge Operations

112. Research and Technical Support Division

DOE-Denver Project Office, Suite 211, 1075 S. Yukon Street, Lakewood, CO 80226

113. A. A. Hagen

DOE-FE, Washington, DC

114. W. Bakker

115. J. D. Batchelor

116. T. Beresovski

117. L. M. Burman

118. E. L. Bui'we 11

119. E, L. Clark

120. N. P. Cochran

121. R. C. Corey

122. T. Cox

1.23. P. Duhame1

124. J. Forst

125. H. Frankel

126. S. I. Freedman

132. T. K. Lau

133. W. G. McDaniel

127. D. Garrett

128. W. S. Harmon

129. H. Jones

130. L. Kindley

131. C. Knudsen

134-139. C. Miller

140. M. Neuworth

141. E. S. Pierce

142. H. E. Poda11

143. J. L. Powe11

144. M. Re11.1y

145. J. Shen

146. A. P. Sikri

147. J. Smith

148. D. K. Stevens

149. W. E. Warnke

150. J. W. Watkins

151. H. L. Weisenfeld

152. D. 0 . Webb

153. P. R. Wieber

DOE-Environment, Washington, DC

154. N. F. Barr

155. R. M. Jimeson

156. W. E. Mott

157. R. W. Wood

Department of Housing and Urban Development, 4517 th St., S.W.,

Washington, DC 20410

158. G. S. Leighton

159. J. H. Rothenberg

University of Kentucky, Institute for Mining and Materials Research,

213 Bradley Ha11, Lexington, KY 40506

160. Theresa Wiley, Institute Librarian

161. 0. J. Hahn

162. J. K. Shau

National Science Foundation, 1800 G Street, N.W., Washington, DC 20550

163. Robert Rabin 
164. Charles B. Sedman, U.S. Environmental Protection Agency, Research Triangle Park, NC 27711

165. N. S. Boodman, Section Supervisor, U.S. Stee1 Corporation Applied. Research Laboratory, 125 Jamison Lane, Monroeville, PA 15146

166-177. ERDA PIttsburgh Energy Research Center, U.S. Energy Research and Development Administration, Attention: Director for J. P. Barreca, 4800 Forbes Ave., Pittsburgh, PA 15213

178-183. The Director, Morgantown Energy Research Center, P.0. Box 800, Morgantown, WV 26506

184. Tetra Tech, Inc., 1911 N. Ft. Myer Drive, Suite 601, Arlington, VA 22209, Attention: Walter McGough, Jr.

185. Cameron Engineers, Attn: Gary L. Baughman, 1315 South Clarkson St., Denver, CO 80213

186. Y. A. Liu, Department of Chemical Engineering, Auburn University, Auburn, Alabama 36830

187-213. Technical Information Center, DOE 